\title{
Sonophoresis Enhanced Transdermal Delivery of Cisplatin in the Xenografted Tumor Model of Cervical Cancer
}

This article was published in the following Dove Press journal: OncoTargets and Therapy

\section{Shanshan Ma (iD) \\ Chang Liu (1D* \\ Bo Li (D) \\ Tingting Zhang \\ Li Jiang \\ Rensheng Wang}

Department of Radiotherapy, The First Affiliated Hospital of Guangxi Medical University, Nanning, People's Republic of China

*These authors contributed equally to this work
Correspondence: Rensheng Wang Department of Radiotherapy, The First Affiliated Hospital of Guangxi Medical

University, 6 Shuang Yong Road, Nanning 53002I, People's Republic of China

Tel +86 77I 5356509

Fax +867715323866

Emailwrsgxmu@I26.com
Background: Transdermal drug delivery system has been researched for a long time because of its advantage in decreasing side effects such as nausea, vomiting, and gastrointestinal disturbance. Sonophoresis has been shown to be very effective in promoting the transdermal delivery of drugs. This study is on purpose to research the feasibility of sonophoresis promoting cisplatin in the treatment of cervical cancer and the optimum drug delivery mode.

Methods: Thirty-two female nude-mice model of cervical cancer were randomly divided into 4 groups ( $\mathrm{n}=8$ in each group): control group without any intervention, low, medium and high concentration groups were treated with the corresponding cisplatin concentrations of $0.2 \mathrm{mg} / \mathrm{mL}, 0.4 \mathrm{mg} / \mathrm{mL}$ and $0.8 \mathrm{mg} / \mathrm{mL}$, respectively, with concurrent sonophoresis applied on the skin of local tumor, $1 \mathrm{~mL}$ at a time, once a day for a total of 5 days. Therapeutic pulsed ultrasound (TPU) was 1.0 MHz, $2.0 \mathrm{~W} / \mathrm{cm}^{2}$ and 60 -min duration. Weight of mice and tumor diameters were measured every day during the intervention. The concentration of cisplatin in tumors was detected by HPLC. Meanwhile, tumor, skin, liver and kidney gross structures and ultrastructure were observed in order to evaluate the effectiveness and safety of experimental conditions. In addition, apoptosis and proliferation-related factors (MPO, Caspase-3, PCNA) were detected by immunohistochemistry, immunofluorescence and TUNEL assay.

Results: The weight of nude mice in each group showed an increasing trend, except for a decrease of weight in the $0.8 \mathrm{mg} / \mathrm{mL}$ group. No obvious tumor inhibition effect was observed. Cisplatin was detected in the $0.4 \mathrm{mg} / \mathrm{mL}$ group and $0.8 \mathrm{mg} / \mathrm{mL}$ group, with relative concentrations of $0.081 \pm 0.033 \mathrm{mg} / \mathrm{mL}$ and $0.111 \pm 0.021 \mathrm{mg} / \mathrm{mL}$, respectively. Both skin and kidney inflammation were observed in the $0.8 \mathrm{mg} / \mathrm{mL}$ group. The expression of MPO, caspase-3 and TUNEL was concentration dependent, with the highest expression in the $0.8 \mathrm{mg} / \mathrm{mL}$ group, followed by the $0.4 \mathrm{mg} / \mathrm{mL}$ group, with no significant differences between the control and the $0.2 \mathrm{mg} / \mathrm{mL}$ group. PCNA was highly expressed in both the control and $0.2 \mathrm{mg} / \mathrm{mL}$ groups but decreased in the $0.4 \mathrm{mg} / \mathrm{mL}$ and $0.8 \mathrm{mg} / \mathrm{mL}$ groups.

Conclusion: Sonophoresis enhanced transdermal delivery of cisplatin in a xenograft tumor model of cervical cancer. Considering the occurrence of skin inflammation and renal injury caused by cisplatin, the recommended concentration to be administered is $0.4 \mathrm{mg} / \mathrm{mL}$.

Keywords: sonophoresis, transdermal drug delivery, cisplatin, cervical cancer

\section{Introduction}

Based on 2015 World Health Organization (WHO) estimates, cancer-related deaths rank the highest in causes of death before 70 years of age. ${ }^{1}$ Surgery, radiotherapy, chemotherapy and molecular targeted therapy are the primary treatment modalities for 
cancer. Chemotherapy plays an important role in local control and distant metastasis of tumors. Nevertheless, chemotherapy results in several systemic side effects such as gastrotoxicity, myelosuppression, nephrotoxicity, ototoxicity, hepatotoxicity, cardiotoxicity, neurotoxicity and allergic reactions. $^{2-4}$ Cisplatin is a metallic compound that possesses square planar geometry and is a widely used antitumor drug. It is dose-dependent, with its efficacy related closely to the concentration of the drug in the tumor. Liver and kidney damage as well as gastrointestinal reactions are the most common side effects of this compound. ${ }^{5}$ Cisplatin has proven to be useful across a myriad of tumors such as sarcomas, lymphomas, germ cell tumors and carcinomas. ${ }^{6}$ It is particularly efficacious in the management of cervical cancer, the most frequently encountered gynecological cancer. ${ }^{7}$ Concurrent administration of cisplatin with radiotherapy is thought to be the optimum model in concurrent chemoradiation therapy (CCRT) ${ }^{8}$ In clinical practice, several patients refuse and withdraw from chemotherapy as they are unable to tolerate the severe side effects, leading to treatment failure. The side effects of chemotherapy caused by cisplatin seriously affect the compliance of patients to chemotherapy, thereby adding psychological and economic burden on the treatment of cervical cancer. Therefore, despite the advent of effective cisplatin-based concurrent chemotherapy, its toxic effect is a significant limiting factor. ${ }^{9-13}$

Several novel techniques of drug administration have been invented. One such example is the transdermal drug delivery system which is widely used in clinical practice because of its advantage in decreasing side effects in comparison to oral administration and injections, especially in the field of dermatology. The skin is an effective diffusion barrier that only allows the passive diffusion of small $(<500 \mathrm{Da})$ lipophilic molecules. Therefore, several ways to enhance transdermal drug delivery has been developed, including physical (iontophoresis, sonophoresis, electroosmosis, lasers, microneedles, etc.) and chemical approaches (microbubbles, nanobubbles, nanodroplets, liposomes, emulsions, micelles, etc.). ${ }^{14}$ Sonophoresis is an ultrasound (US)-based modality that enhances the permeability of the skin in order to allow transmission of chemicals through the skin in a noninvasive and reversible manner. ${ }^{15}$ The potential of sonophoresis-enhanced transdermal drug delivery has been researched and is a proven means of noninvasive administration of compounds, including hormones, non-steroidal antiinflammatory drugs (NSAID), fentanyl, lidocaine and mannitol. ${ }^{16}$ It has also been investigated in the domains of gene therapy and vaccination. ${ }^{17}$ However, sonophoresis in the context of transdermal permeation of cisplatin has rarely been reported, limiting the availability of an appropriate treatment protocol involving the two modalities.

Myeloperoxidase (MPO) is a heme iron enzyme released by activated neutrophils, monocytes, and macrophages. It is a marker of neutrophil activation and a member of the intercellular triggered-apoptosis mechanism. It represents the gold standard for the quantification of neutrophil infiltration. ${ }^{18}$ Caspase- 3 is a key protease in mammalian apoptosis that lies at the core of the apoptotic cascade and is also known as the "central processing unit" of apoptosis. It represents a crucial checkpoint in the apoptotic protease cascade reaction. ${ }^{19}$ Replication in eukaryotic cells are dependent on a molecule known as the proliferating cell nuclear antigen (PCNA), which acts as a DNA clamp and a processivity factor for DNA polymerase $\delta$. DNA synthesis is strongly related to PCNA. PCNA can be used as an indicator of cell proliferation status given its role as a critical modulator of cell proliferation. $^{20}$ These three factors are classic indicators of tumor inflammation, apoptosis and proliferation.

Considering the specificity of the anatomical location of cervical cancer (the tumor being exposed in a natural lumen) and the role of chemotherapy as a cornerstone in its management, cervical cancer is the most suitable cancer for the investigation of sonophoresis-mediated transdermal delivery of cisplatin in clinical practice. Therefore, our investigation is designed to determine the optimum administration model (drug concentration, visual safe dose) of cisplatin in the presence of ultrasound administration in a xenograft model of cervical carcinoma in nude mice. Our experiment utilized modalities such as high-performance liquid chromatography (HPLC) to determine cisplatin concentration, hematoxylineosin (HE) staining and transmission electron microscope (TEM) for examination of tumor, liver, kidney and skin tissues, growth curve and tumor-inhibition rate of tumors in nude mouse, immunohistochemical and immunofluorescent analyses for detection of MPO, Caspase-3 and PCNA as well as the TUNEL assay for cell apoptosis. Our aim is to determine a method that is able to improve tumor drug concentration and to enhance its anti-tumor efficacy without an increasing risk of systemic toxicity.

\section{Materials and Methods \\ Cell Culture}

Cervical cancer cells ( $\mathrm{SiHa}$ ) were obtained from the Institute of Biochemistry and Cell Biology, Chinese 
Academy of Sciences (Shanghai, China). All cells were incubated at $37^{\circ} \mathrm{C}$ in a humidified atmosphere with $5 \%$ $\mathrm{CO}_{2}$. Cells were cultivated in minimum essential medium (MEM; Gibco Co., USA) supplemented with $10 \%$ fetal calf serum (FBS; Gibco Co., USA). Potassium penicillin $(100 \mathrm{U})$ and $100 \mu \mathrm{g}$ streptomycin sulfate $/ 1 \mathrm{~mL}$ were added into the culture medium.

\section{Animal and Xenografted Tumor Model of Cervical Cancer}

Specific pathogen-free (SPF) female nude BALB/c mice (4 weeks old, 12 15g) were purchased from Guangxi Medical University Laboratory Animal Center and maintained in pathogen-free conditions in it. A total of $2 \times 10^{6} \mathrm{SiHa}$ cells were suspended in $100 \mu \mathrm{L}$ PBS and then injected into the left subcutaneous axilla of female BALB/c athymic nude mouse. In total, 32 mice were included in experimental groups. Weight of mice and diameters of tumor were examined each day in order to derive the tumor volumes $\left(\right.$ width $^{2} \times$ length $\times 0.5$ ) .

\section{In vivo Treatment of Subcutaneous Xenograft Tumors}

As soon as tumor sizes reached $100 \mathrm{~mm}^{3}$ in size, all experimental animals were randomly divided into four groups ( $\mathrm{n}=8$ in each group): control group without any intervention, low, medium and high concentration groups which were treated with the corresponding cisplatin concentration $0.2 \mathrm{mg} / \mathrm{mL}, \quad 0.4 \mathrm{mg} / \mathrm{mL}$ and $0.8 \mathrm{mg} / \mathrm{mL}$, respectively. Cisplatin was administered under sonophoresis on the skin of local tumor after anesthesia by pentobarbital sodium, $1 \mathrm{~mL}$ cisplatin at a time, each day for five consecutive days. The concentration gradients of cisplatin were proposed by pharmacologists according to the concentration of cisplatin in the clinical practice. Therapeutic pulsed ultrasound (TPU) was administered for 20 mins at an intensity of $2.0 \mathrm{~W} / \mathrm{cm}^{2}$ and a frequency of $1.0 \mathrm{MHz} .^{21}$ Ultrasonic conductometric compound therapeutic instrument WNDZZ-2TD-E was used for sonophoresis (Guilin Wandom Medical Apparatus CO.LTD, Guilin, China). Weight of mice and tumor diameters were measured daily. After the dose of drug administration, all mice were killed in order to extract the tumors, skins (contacted with the ultrasonic electrode), livers and kidneys were excised and weighed. All animal experiments and care administered were regulated by protocols set by the Guangxi Medical University Animal Care and Use Committee, People's Republic of China.

\section{High-Performance Liquid Chromatography (HPLC)}

The tumor tissue was homogenized at low temperatures (on the ice) and centrifuged for $15 \mathrm{~min}$ to collect the supernatant. As the ultraviolet absorption peaks can only be detected after cisplatin is combined with diethyldithiocarbamate (DDTC), DDTC was added into the supernatant to combine with the free cisplatin. The DDTC-cisplatin compound was then extracted by chloroform. After the chloroform layer was absorbed and the argon dried, the residue was dissolved with ethyl acetate, centrifuged for 5 min, and the supernatant was taken for further analysis. Separations using chromatography were done using an LC-20AB (SPD-20A UV-VIS Detector, CTO-20AC Column Oven, SIL-20AC Autosampler, LC-20AB Solvent Delivery Unit, Ver 1.25 Workstation). The liquid chromatograph was equipped with an autosampler, column thermostat, degasser and binary gradient pump. All chromatographic separations were carried out using the GPC18 (250 mm $4.6 \mathrm{~mm}$ i.d., 5um) analytical column. The wavelength of the detector was $254 \mathrm{~nm}$ and the working conditions were programmed to be at a drying gas flow (nitrogen) at a rate of $1.0 \mathrm{~mL} / \mathrm{min}$ and at a capillary temperature of 30 degrees. The mobile phase is $30 \%$ water and $70 \%$ methanol. The chromatographic data were recorded and analyzed using the Chem Station and Data Analysis software from Agilent, United States. An external standard model was used to perform quantitative determinations. Relative concentrations of DDTC-cisplatin were calculated with a standard curve constructed with a standard cisplatin aqueous solution. A 5-point plot had calibration curves ranging from 0.5 to $50 \mathrm{mg} / \mathrm{mL}$. Acceptable linearity $\left(\mathrm{R}^{2}>0.999\right)$ was preserved. All calibration curves possessed an $\mathrm{R}^{2}=0.99$ coefficient of determination. The results are depicted in terms of $\mathrm{mg}$ per $\mathrm{mL}$ of extract $(\mathrm{mg} / \mathrm{mL})$.

\section{Transmission Electron Microscope}

The tumor, skin, liver and kidney tissues were fixed with glutaraldehyde for transmission electron microscope analysis to detect ultrastructural changes. Transmission electron microscope (Hitachi-7650, Tokyo, Japan) was used to collect the corresponding images.

\section{Histopathology}

Tissue samples were fixated in $10 \%$ formalin, subjected to alcohol dehydration and xylol clearance before being 
paraffinized using a tissue processor. Blocks were sectioned into $4 \mu \mathrm{m}$ in thickness and stained with hematoxylin and eosin. Finally, light microscopy was used to evaluate the changes in tissues.

\section{Immunohistochemical and Immunofluorescent Analyses}

All the paraffin-embedded sections were cut into $4 \mu \mathrm{m}$ sections. Paraffin sections were dewaxed and hydrated, then washed with PBS thrice, each time for 3 mins. The repair antigen was boiled with $0.01 \mathrm{~mol} / \mathrm{L}$ citrate buffer at pH6.0 for $90 \mathrm{~s}$, then washed 3 times with PBS for 3 mins at each time. The substrate was incubated with $3 \% \mathrm{H}_{2} \mathrm{O}_{2}$ at room temperature for 15 mins, then rinsed with PBS 3 times for 3 mins each rinse. Samples were then serum sealed for 40 mins. Primary antibodies were added prior to an overnight incubation at $4{ }^{\circ} \mathrm{C}$. The primary antibodies added include monoclonal rabbit anti-PCNA antibody (Abcam, Cambridge, MA, USA), polyclonal rabbit anti-MPO antibody (Bioss, Boston, MA, USA) and polyclonal rabbit anti-Cleaved Caspase-3 antibody (Affinity, Cincinnati, OH, USA). The second antibody labeled with biotin was then used to incubate the samples for 20 mins at room temperature. Substrates were then rinsed with PBS thrice. Streptomyces anti-biotin peroxidase solution was added prior to a 20 -min incubation period at room temperature. Samples were rinsed with PBS thrice. Finally, $\mathrm{DAB}$ color rendering and hematoxylin reddening were performed.

For immunofluorescent analysis, the previous steps as described in immunohistochemical staining were done. After 10 mins of incubation with 3\% hydrogen peroxide, substrates were incubated with 5\% BSA at room temperature for 30 mins. Then, the sections were immunostained with monoclonal rabbit anti-PCNA antibody (Abcam, 1:100 dilution), polyclonal rabbit anti-MPO antibody (Bioss, 1:100 dilution) and polyclonal rabbit anti-Cleaved Caspase-3 antibody (Affinity, 1:100 dilution) at $4^{\circ} \mathrm{C}$ overnight. After incubation with a primary antibody, fluorescence secondary antibody (ZSGB-BIO, Beijing, PRC) was added and incubated at $37^{\circ} \mathrm{C}$ for 30 mins. DAPI was then added and the sample incubated at room temperature for 10 mins. The water-soluble tablet was sealed and observed by a fluorescence microscope.

A microscopic examination was performed and randomly selected from each chamber. The semi-quantitative method was used for evaluation, staining intensity and range were observed under an optical microscope with $400 \times$ magnification by three experienced pathologists in a double-blind manner.

\section{TUNEL Assay}

The TUNEL (Terminal deoxynucleotidyl transferasemediated dUTP nick-end labeling) staining was carried out using an in-situ apoptotic cell detection kit based on protocols stipulated by the manufacturer (Roche Group). The cytoplasm was stained with yellow or brown. Images of the representative sections were captured using a microscope and analyzed by three experienced pathologists in a double-blind manner.

\section{Statistical Analysis}

All data are depicted in terms of mean \pm standard deviation (SD) based on a composite of results performed in triplicate. The statistical significance was identified by repeated analyses of variance and one-way analysis of variance (ANOVA). All statistical analyses were carried out using the IBM SPSS software (version 25). Statistical significance was defined as $P<0.05$.

\section{Results}

\section{Weight and Tumor Changes of Nude Mice}

There were no adverse effects on the feeding habits and mental status of nude mice in groups except the $0.8 \mathrm{mg} /$ $\mathrm{mL}$ group. Mice in $0.8 \mathrm{mg} / \mathrm{mL}$ group demonstrated poorer feeding habits and deteriorated mental states, with their weights demonstrating a significant decreased trend. The other groups all demonstrated increased bodyweights. After repeated-measures analysis of variance was performed, we found that there were statistical differences between $0.8 \mathrm{mg} / \mathrm{mL}$ group and other groups $(P<0.001)$, and no statistical difference among the control group, $0.2 \mathrm{mg} / \mathrm{mL}$ group and $0.4 \mathrm{mg} / \mathrm{mL}$ group. Weight change of nude mice during intervention was presented in Figure 1A.

The tumor volume of nude mice in each group showed an increasing trend, and the difference of tumor volume and weight between each group was not statistically significant $(P>0.05)$. We did not observe a significant tumor-inhibition effect. Tumor volume change of nude mice during the intervention and the tumor weight after animals were sacrificed are presented in Figure 1B and C. Representative tumors from mice after treatment are shown in Figure 1D. 

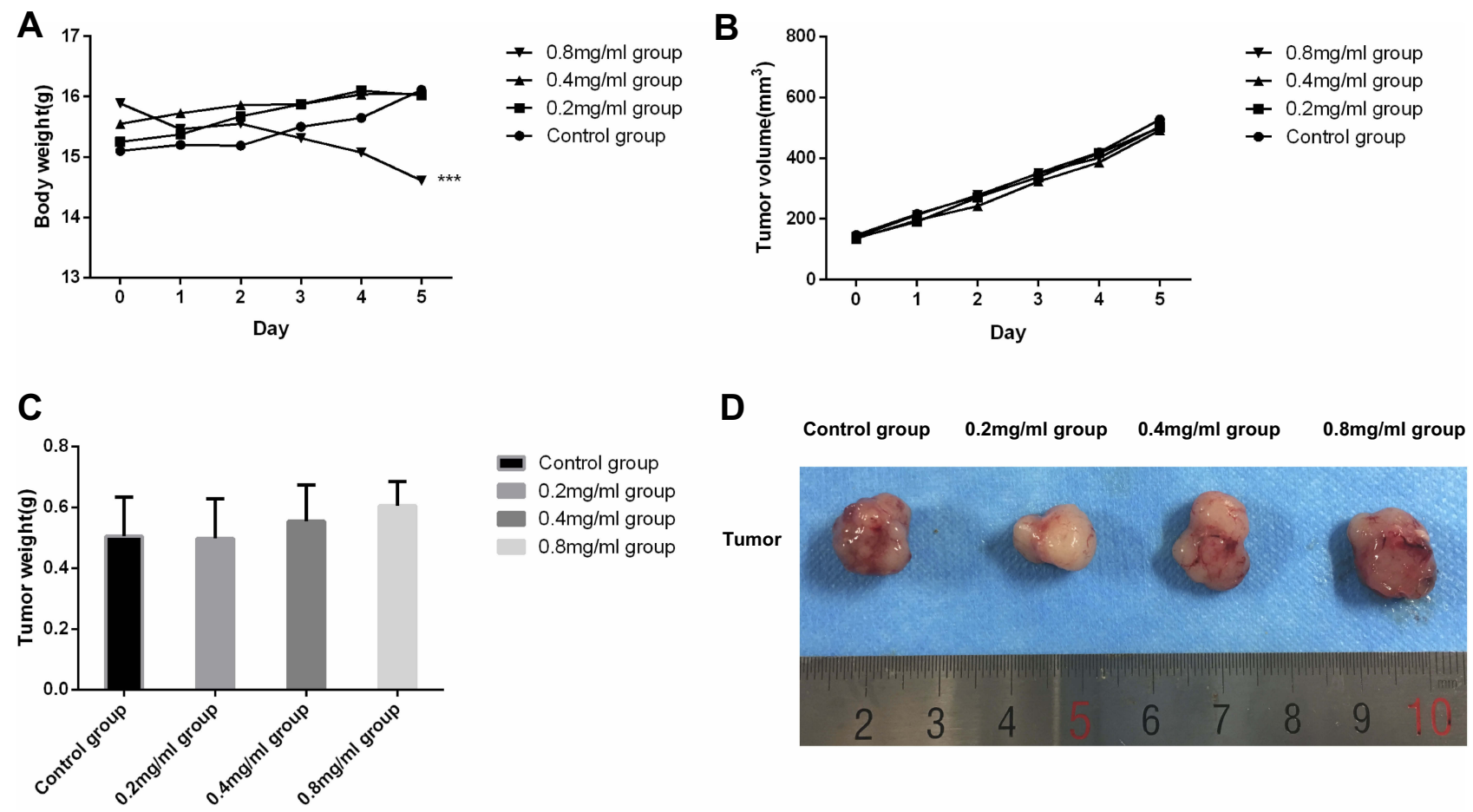

Figure I (A) Weight change curve of nude mice $(\mathrm{g})$ during intervention $(\mathrm{n}=\mathbf{8})$. (B) Tumor volume change curve of nude mice $(\mathrm{g})$ during intervention $(\mathrm{n}=\mathbf{8})$. (C) Tumor weight of mice in the different groups on day $5(n=8)$. (D) Representative tumors from mice in the different groups on day 5 . ***P $<0.00 \mathrm{I}$ versus the control group.

\section{HPLC Profile of Cisplatin in Tumor of Nude Mice}

Given the strong binding force between cisplatin and protein, it is difficult to determine the total cisplatin content in tissues. Therefore, our experiment measures the amount of cisplatin in tissues that can complexed with DDTC within 30 mins. Previous studies have reported that this component of cisplatin is the component more strongly related to clinical therapeutic effect. $^{22,23}$ DDTC-cisplatin in tumor tissues is identified and analyzed based on the linear regression equation of $\mathrm{Y}=5.779742 \times 10^{-8} \mathrm{X}-0.0199$ $\left(\mathrm{R}^{2}=0.9976\right)$, with $\mathrm{Y}$ representing concentration and $\mathrm{X}$ the peak area. DDTC-cisplatin peak was not detected in the control and/or $0.2 \mathrm{mg} / \mathrm{mL}$ groups. The relative concentrations of cisplatin in the $0.4 \mathrm{mg} / \mathrm{mL}$ and the $0.8 \mathrm{mg} / \mathrm{mL}$ groups were $0.081 \pm 0.033 \mathrm{mg} / \mathrm{mL}$ and $0.111 \pm 0.021 \mathrm{mg} / \mathrm{mL}$, respectively. These variabilities were deemed to be statistically significant $(P=0.005)$. Figure 2A demonstrates a chromatogram of DDTCcisplatin standards and a representative chromatogram of each group. Figure 2B demonstrates the standard curve of DDTC-cisplatin. Figure 2C demonstrates the quantitative analyzed results in different groups.

\section{Morphology Changes of Tumor, Skin, Kidney and Liver}

\section{Tumor}

The tumor cells in the control group were distributed in clumps or sheets, closely arranged, with different cell sizes, large nuclei, dark staining, and possessed obvious nucleoli. Abundant small blood vessels could be seen in the tumor tissues, with relatively complete vascular structures, with no exudation of red blood cells between tissues. There was no obvious change except for some granulocytes and lymphocyte infiltration in $0.2 \mathrm{mg} / \mathrm{mL}$ group. In $0.4 \mathrm{mg} / \mathrm{mL}$ group and $0.8 \mathrm{mg} / \mathrm{mL}$ group, there were many inflammatory cells (predominantly consisting of granulocytes and lymphocytes) infiltrate. There was incomplete tumor angiogenesis as evidenced by the disrupted continuity of vascular endothelium and a large number of red blood cells present between tissues. Representative images in each group are shown in Figure 3.

\section{Skin}

With the exception of the $0.8 \mathrm{mg} / \mathrm{mL}$ group, there were no abnormal inflammatory responses demonstrated by the other groups. In the $0.8 \mathrm{mg} / \mathrm{mL}$ group, there were numerous inflammatory cells infiltrate, a thinner cuticle with the 


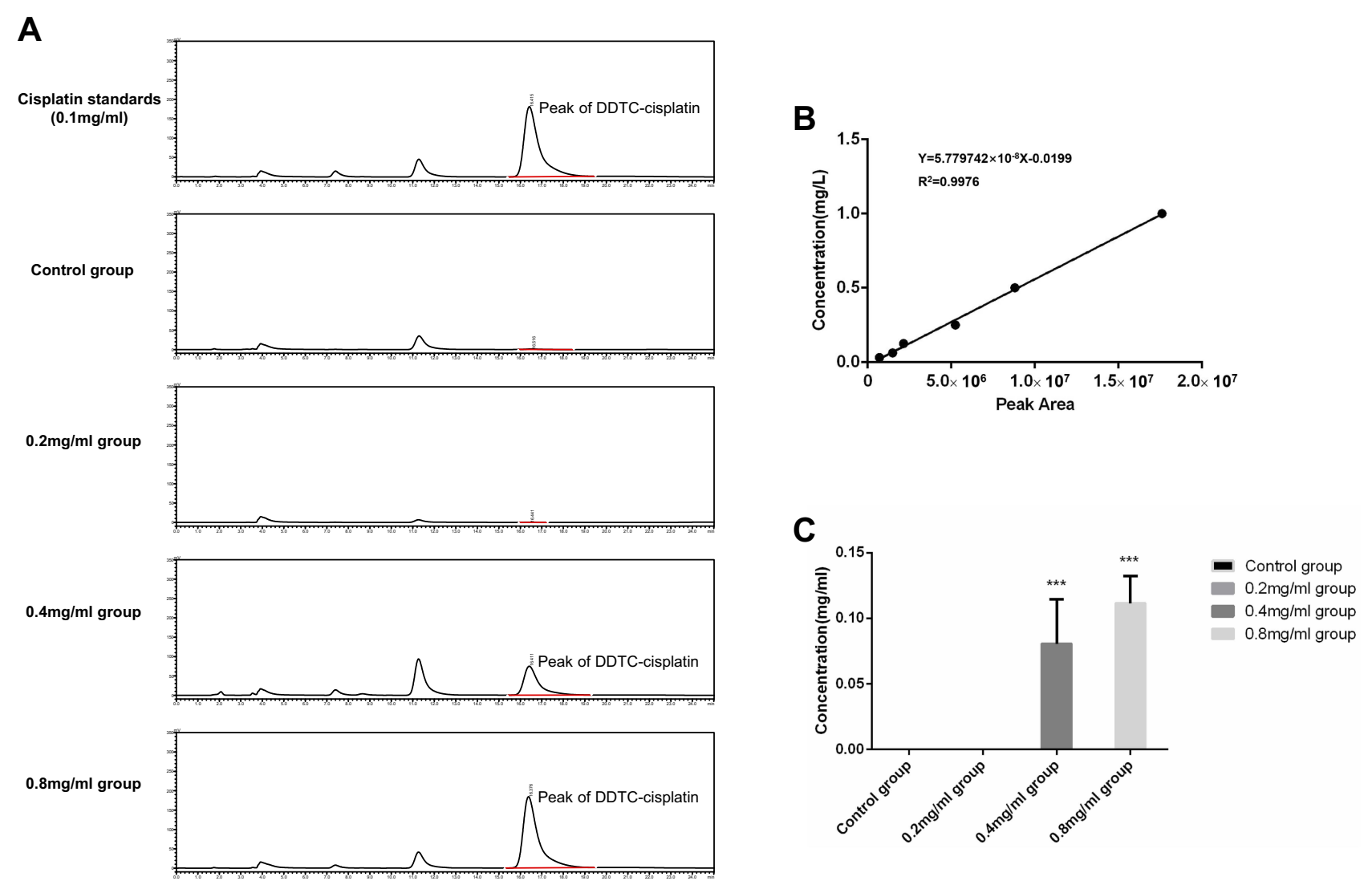

Figure 2 (A) Chromatogram of cisplatin standards and representative chromatogram of each group. (B) Standard curve of DDTC-cisplatin. (C) Relative concentration of cisplatin in the different groups on day $5(n=8)$. $* * * P<0.001$ versus the control group.

presence of intercellular edema, and vesicles within the epidermis. All other groups demonstrated a dense and continuous cuticle with no obvious inflammatory cell infiltration in the subcutaneous tissue. There was also no obvious damage to the sweat glands and hair follicle structures. Representative images in each group are shown in Figure 3.

\section{Kidney}

With the exception of the $0.8 \mathrm{mg} / \mathrm{mL}$ group which demonstrated a small amount of inflammatory cells such as lymphocyte and neutrophil infiltration, there were no abnormal changes observed in the other groups. In the $0.8 \mathrm{mg} / \mathrm{mL}$ group, the epithelial content was not clear, the renal stroma was infiltrated by inflammatory cells, kidney tubules were dilatated and hyperemic, and the epithelial cells of the tubules were visibly turbid and swollen. Conversely, all other cells demonstrated clear boundaries of renal cortex and medulla, complete glomerular structures, normal-sized renal tubules and an intact epithelium, and no inflammatory cell infiltration was observed in the renal stroma. Representative images in each group are shown in Figure 3.

\section{Liver}

No significant abnormalities were found in Liver groups. The hepatocytes were neatly arranged, and the hepatic sinuses were aligned around the center of the hepatic lobule with the neatly arranged septum of the hepatic cords. The cytoplasm was plump, the nuclear chromatin was clear, and the boundaries were clear. Representative images in each group are shown in Figure 3.

\section{Ultrastructure Changes of Tumor, Skin, Kidney and Liver Tumor}

In the control group and $0.2 \mathrm{mg} / \mathrm{mL}$ group, the structures of tumor cells were basically normal, with tight arrangements and narrow intercellular space. The cytoplasm was large, and nucleoli were obvious. There were lots of cytoplasmic organelles, and some endoplasmic reticulum was expanded to form vesicles. In the $0.4 \mathrm{mg} / \mathrm{mL}$ group and $0.8 \mathrm{mg} / \mathrm{mL}$ group, there were higher proportions of apoptotic cells. The 


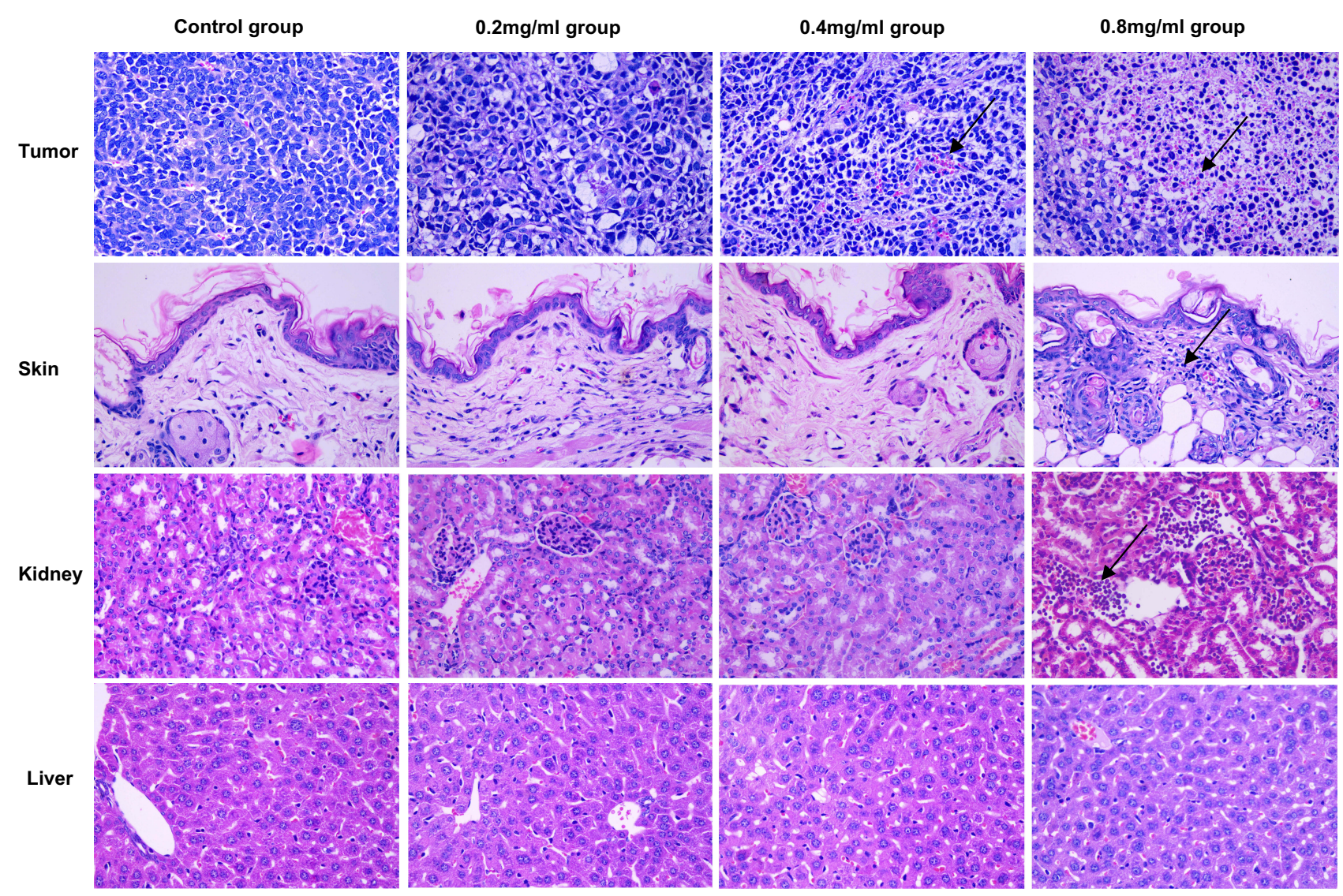

Figure 3 Histological images from the major organs of mice in the different groups on day 5 . Tissues were collected from the tumor, skin, kidney and liver. Images were taken at $\times 400$ magnification with standard hematoxylin and eosin $(\mathrm{HE})$ staining. The arrow indicated the areas of inflammatory cell infiltration.

tumor cells were loosely arranged with large intercellular spaces, the nuclei of tumors were irregular, and the nucleoli were well defined. The endoplasmic reticulum expanded to form vesicles in the cytoplasm of the tumor cells, and numerous mitochondria were seen swollen and fractured in the cytoplasm. Representative images are shown in Figure 4.

\section{Skin}

The stratum corneum did not develop any structural damage as a result of ultrasound exposure. The cuticle was distributed in a banded manner, with dense and closely packed layers. Some cell debris and secretions were attached to the cuticle. In the $0.8 \mathrm{mg} / \mathrm{mL}$ group, the cytoplasm of the granulosa cells was loose, with a small number of mitochondria swollen and broken, and keratin filaments were able to be seen in the granular layer. Representative images are shown in Figure 4.

\section{Kidney}

In control group, $0.2 \mathrm{mg} / \mathrm{mL}$ and $0.4 \mathrm{mg} / \mathrm{mL}$ groups, the renal tissue structure was normal, the renal epithelial nucleus was round or oval, the nuclear membrane was smooth, the nucleus and nuclear pore were clear, the cytoplasm and organelles were abundant, a large number of mitochondria were evenly dispersed and maintain normal morphology, the internal ridge structure was clear, the rough endoplasmic reticulum was neatly arranged, and abundant ribosomes were distributed on it. In the $0.8 \mathrm{mg} / \mathrm{mL}$ group, the intercellular space between the renal epithelial cells was significantly enlarged, with more mitochondrial swelling and mitochondrial cristae rupture. There was numerous lymphocyte infiltration around the nucleus. Representative images are shown in Figure 4.

\section{Liver}

The overall structure of the liver cells was normal, the nuclear membrane nucleoli were clearly visible, and the intracellular organelles such as the mitochondrial endoplasmic reticulum were abundant in the cytoplasm. Representative images are shown in Figure 4. 


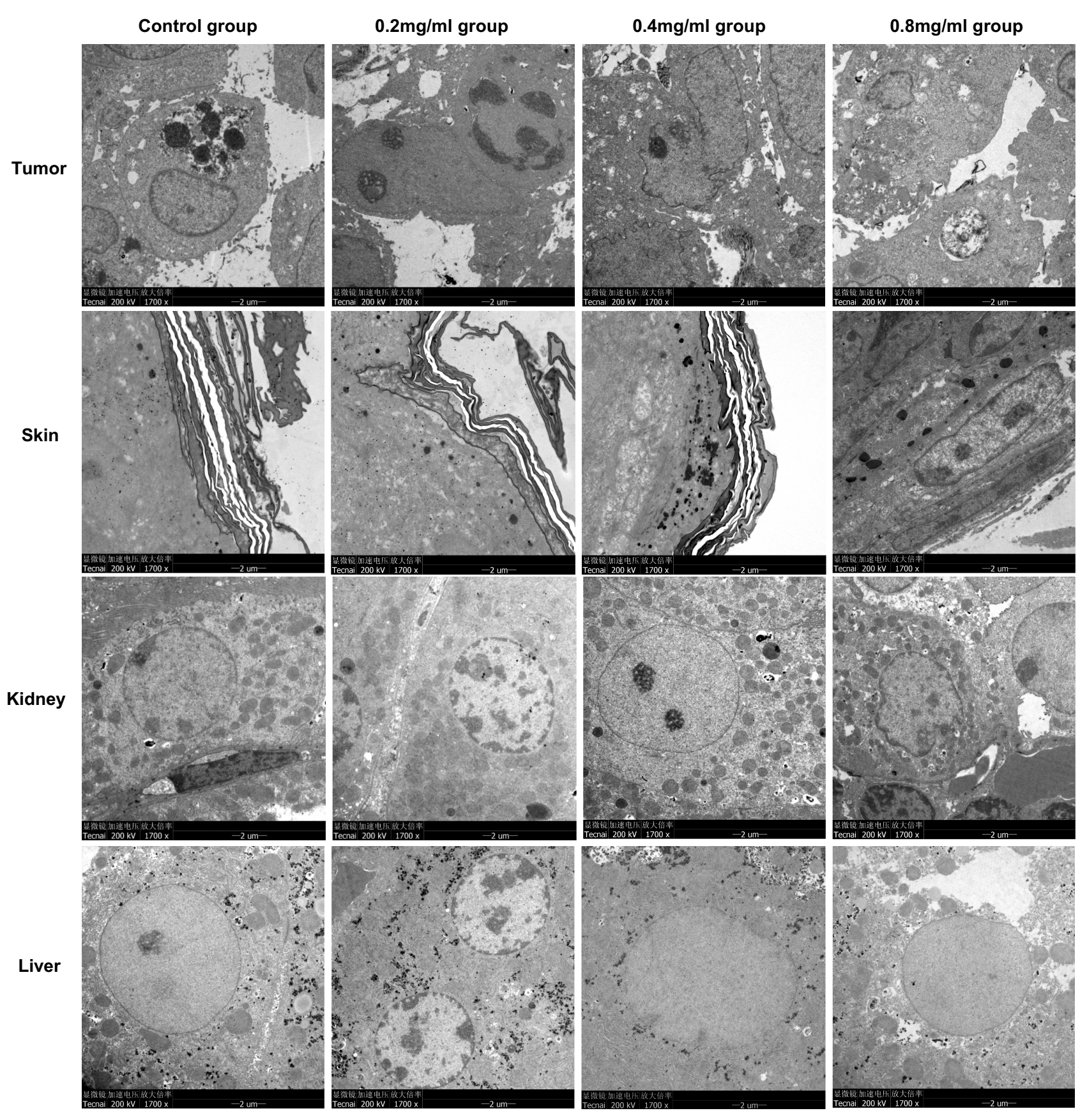

Figure 4 Representative TEM $\times 1700$ images of tumor, skin, kidney and liver in each group.

\section{Effect of Sonophoresis on Tumor} Apoptosis and Proliferation in vivo Immunohistochemical Assay

To explore the effect of sonophoresis on the molecular level, we analyzed factors of apoptosis (MPO, Caspase-3, TUNEL) and proliferation (PCNA) in our study.

MPO was expressed in all groups. In contrast to the control group, MPO expression in the $0.4 \mathrm{mg} / \mathrm{mL}$ group $(P=0.001)$ and the $0.8 \mathrm{mg} / \mathrm{mL}$ group $(P<0.001)$ was significantly increased.
MPO levels between the control and the $0.2 \mathrm{mg} / \mathrm{mL}$ groups $(P=0.825)$ were not significantly different. MPO expression in each group is shown in Figure 5A.

Caspase- 3 was expressed in all groups with the highest level in $0.8 \mathrm{mg} / \mathrm{mL}$ group. This molecule was not obviously present in the control and the $0.2 \mathrm{mg} / \mathrm{mL}$ groups, with no significantly different levels between these groups $(P=0.288)$. There were marked alterations among the control group and $0.4 \mathrm{mg} / \mathrm{mL}$ group and $0.8 \mathrm{mg} / \mathrm{mL}$ group $(P=0.003$, 

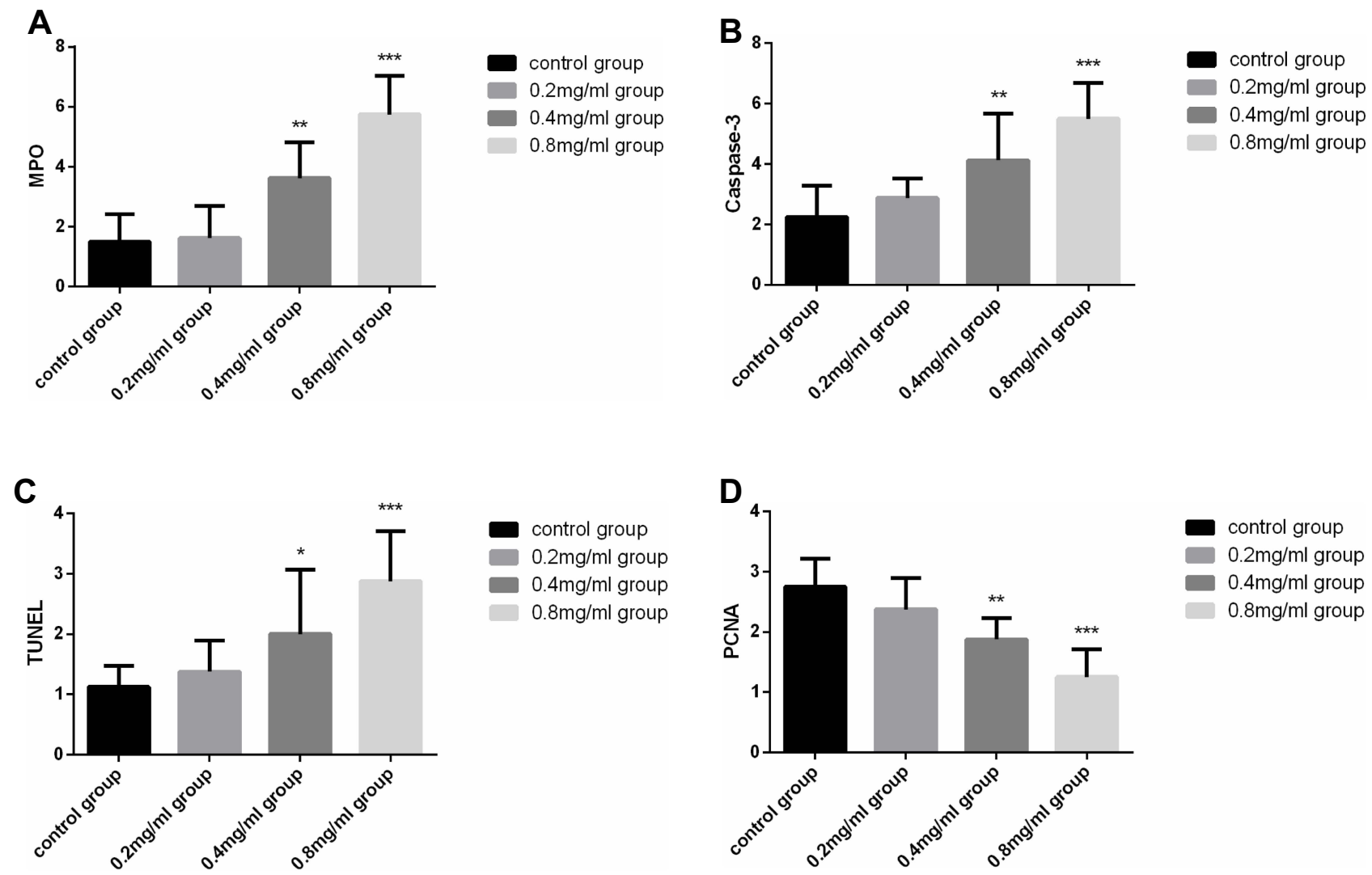

Figure 5 (A) MPO expression in each group $(n=8)$. (B) Caspase-3 expression in each group $(n=8)$. (C) The results of TUNEL assay in each group ( $n=8)$. (D) PCNA expression in each group $(\mathrm{n}=8)$. $* \mathrm{P}<0.05, * * \mathrm{P}<0.01$ and $* * * \mathrm{P}<0.001$ versus the control group.

$P<0.001$, respectively). Statistically significant differences were present between the $0.2 \mathrm{mg} / \mathrm{mL}$ group and $0.4 \mathrm{mg} / \mathrm{mL}$ group $(P=0.039)$, between $0.2 \mathrm{mg} / \mathrm{mL}$ group and $0.8 \mathrm{mg} / \mathrm{mL}$ group $(P<0.001)$, and between $0.4 \mathrm{mg} / \mathrm{mL}$ group and $0.8 \mathrm{mg} /$ $\mathrm{mL}$ group $(P=0.024)$. Caspase- 3 expression in each group is shown in Figure 5B.

TUNEL staining indicated that the average absorbance $(A)$ of positive cells expressing apoptosis in the $0.4 \mathrm{mg} / \mathrm{mL}$ and $0.8 \mathrm{mg} / \mathrm{mL}$ groups was significantly higher versus the control group ( $P=0.01, P<0.001$, respectively). Values between the control group and $0.2 \mathrm{mg} / \mathrm{mL}$ group were not statistically different $(P=0.696)$. Conversely, there was statistically significant differences between the $0.2 \mathrm{mg} / \mathrm{mL}$ and $0.4 \mathrm{mg} / \mathrm{mL}$ groups $(P=0.025)$, and between $0.2 \mathrm{mg} / \mathrm{mL}$ and $0.8 \mathrm{mg} / \mathrm{mL}$ groups $(P<0.001)$. Expression in $0.8 \mathrm{mg} / \mathrm{mL}$ groups was also higher than $0.4 \mathrm{mg} / \mathrm{mL}$ group $(P=0.01)$. The results of TUNEL assay in each group are shown in Figure 5C.

PCNA showed that positive cells were high in each group. The control group possessed the highest levels of positive cells. The expression decreased across the $0.2 \mathrm{mg} /$ $\mathrm{mL}$ group, $0.4 \mathrm{mg} / \mathrm{mL}$ and $0.8 \mathrm{mg} / \mathrm{mL}$ groups. We did not uncover any differences between the control group and
$0.2 \mathrm{mg} / \mathrm{mL}$ group $(P=0.109)$. However, both the $0.4 \mathrm{mg} /$ $\mathrm{mL}$ and $0.8 \mathrm{mg} / \mathrm{mL}$ groups possessed statistically significant differences when analyzed against the control group ( $P=0.001, P<0.001$, respectively). When analyzed against the $0.2 \mathrm{mg} / \mathrm{mL}$ group, both the $0.4 \mathrm{mg} / \mathrm{mL}$ and $0.8 \mathrm{mg} / \mathrm{mL}$ groups also differed significantly $(P=0.036, P<0.001$, respectively). The $0.4 \mathrm{mg} / \mathrm{mL}$ group also possessed raised values in comparison to the $0.8 \mathrm{mg} / \mathrm{mL}$ group $(P=0.01)$. The expression negatively correlated with cisplatin concentration. PCNA expression in each group is shown in Figure 5D.

The analysis results of the immunohistochemical assay are included in Table 1. Representative immunohistochemical images of each factor in the different groups are shown in Figure 6.

\section{Immunofluorescent Assay}

We also detected the expression of MPO, Caspase-3, TUNEL and PCNA by immunofluorescence. They showed a similar trend as the immunohistochemical assay results. The expression results are as follows: MPO, Caspase-3, TUNEL $(0.8 \mathrm{mg} / \mathrm{mL}$ group $>0.4 \mathrm{mg} / \mathrm{mL}$ group $>0.2 \mathrm{mg} /$ $\mathrm{mL}$ group and control group), PCNA $(0.8 \mathrm{mg} / \mathrm{mL}$ group 
Table I Scores of MPO, Caspase-3, TUNEL, PCNA in Different Groups (Mean \pm SD, $n=8$ in Each Group)

\begin{tabular}{|l|l|l|l|l|l|}
\hline & $\begin{array}{l}\text { Control } \\
\text { Group }\end{array}$ & $\begin{array}{l}\mathbf{0 . 2} \mathbf{~ m g} / \\
\mathbf{m L}\end{array}$ & $\begin{array}{l}\mathbf{0 . 4} \mathbf{~ m g} / \\
\mathbf{~ m L}\end{array}$ & $\begin{array}{l}\mathbf{0 . 8} \mathbf{~ m g} / \\
\mathbf{~ m L}\end{array}$ & P-value \\
\hline MPO & $1.50 \pm 0.93^{\mathrm{a}}$ & $1.63 \pm 1.06$ & $3.63 \pm 1.19$ & $5.75 \pm 1.28$ & $0.000^{*}$ \\
Caspase-3 & $2.25 \pm 1.04^{\mathrm{b}}$ & $2.88 \pm 0.64$ & $4.13 \pm 1.55$ & $5.50 \pm 1.20$ & $0.000^{*}$ \\
TUNEL & $1.13 \pm 0.35^{\mathrm{c}}$ & $1.25 \pm 0.46$ & $2.00 \pm 0.76$ & $2.88 \pm 0.84$ & $0.000^{*}$ \\
PCNA & $2.75 \pm 0.46^{\mathrm{d}}$ & $2.38 \pm 0.52$ & $1.88 \pm 0.35$ & $1.25 \pm 0.46$ & $0.000^{*}$ \\
\hline
\end{tabular}

Notes: *Statistically significant; ${ }^{\text {a }}$ There were statistical differences in control and $0.4 \mathrm{mg} / \mathrm{mL}$ group $(P=0.00 \mathrm{I})$, control and $0.8 \mathrm{mg} / \mathrm{mL}$ group $(P<0.00 \mathrm{I}), 0.2 \mathrm{mg} / \mathrm{mL}$ and $0.4 \mathrm{mg} / \mathrm{mL}$ group $(P=0.00 \mathrm{I}), 0.2 \mathrm{mg} / \mathrm{mL}$ and $0.8 \mathrm{mg} / \mathrm{mL}$ group $(P<0.00 \mathrm{I}), 0.4 \mathrm{mg} / \mathrm{mL}$ and $0.8 \mathrm{mg} / \mathrm{mL}$ group $(P=0.00 \mathrm{l})$; ${ }^{\mathrm{b}}$ There were statistical differences in control and $0.4 \mathrm{mg} / \mathrm{mL}$ group $(P=0.003)$, control and $0.8 \mathrm{mg} / \mathrm{mL}$ group $(P<0.00 \mathrm{I}), 0.2 \mathrm{mg} / \mathrm{mL}$ and $0.4 \mathrm{mg} / \mathrm{mL}$ group $(P=0.039), 0.2 \mathrm{mg} / \mathrm{mL}$ and $0.8 \mathrm{mg} / \mathrm{mL}$ group $(P<0.001), 0.4 \mathrm{mg} / \mathrm{mL}$ and $0.8 \mathrm{mg} / \mathrm{mL}$ group $(P=0.024)$; ${ }^{\mathrm{C}}$ There were statistical differences in control and $0.4 \mathrm{mg} / \mathrm{mL}$ group $(P=0.0 \mathrm{l})$, control and $0.8 \mathrm{mg} / \mathrm{mL}$ group $(P<0.00 \mathrm{I}), 0.2 \mathrm{mg} / \mathrm{mL}$ and $0.4 \mathrm{mg} / \mathrm{mL}$ group $(P=0.025), 0.2 \mathrm{mg} / \mathrm{mL}$ and $0.8 \mathrm{mg} / \mathrm{mL}$ group $(P<0.001), 0.4 \mathrm{mg} / \mathrm{mL}$ and $0.8 \mathrm{mg} / \mathrm{mL}$ group $(P=0.0 \mathrm{I})$; ${ }^{\mathrm{d}}$ There were statistical differences in control and $0.4 \mathrm{mg} / \mathrm{mL}$ group $(P=0.00 \mathrm{I})$, control and $0.8 \mathrm{mg} / \mathrm{mL}$ group $(P<0.00 \mathrm{I}), 0.2 \mathrm{mg} / \mathrm{mL}$ and $0.4 \mathrm{mg} / \mathrm{mL}$ group $(P=0.036), 0.2 \mathrm{mg} / \mathrm{mL}$ and $0.8 \mathrm{mg} / \mathrm{mL}$ group $(P<0.00 \mathrm{I}), 0.4 \mathrm{mg} / \mathrm{mL}$ and $0.8 \mathrm{mg} / \mathrm{mL}$ group $(P=0.0 \mathrm{l})$.

Abbreviations: $\mathrm{SD}$, standard deviation; $\mathrm{n}$, number; $\mathrm{mg}$, milligram; $\mathrm{mL}$, milliliter.

$<0.4 \mathrm{mg} / \mathrm{mL}$ group $<0.2 \mathrm{mg} / \mathrm{mL}$ group and control group). The representative immunofluorescence images of each factor in the different groups are shown in Figure 7.

\section{Discussion}

The therapeutic application of high ultrasound frequency sonophoresis (HFS) ( $\geq 0.7 \mathrm{MHz}$ ) has been used since the 1950 s. $^{24}$ In 1995, Mitragotri et $\mathrm{al}^{25}$ published a paper in Science demonstrating that macromolecules bigger than insulin such as erythropoietin $(48 \mathrm{kDa})$ and interferon- $\gamma$ (17 kDa) could be administered through the skin at therapeutic levels. The study sparked intense research into the field of ultrasound-assisted drug delivery. Although the mechanisms underlying sonophoresis-augmented skin permeability have not been fully described, the general consensus is that the process is mediated by acoustic cavitation. Other contributing factors include mechanical effects, generation of convective velocities and thermal effects. ${ }^{26}$ This investigation focused on the clinical impact of ultrasoundenhanced drug delivery and the underlying mechanisms.

In clinical practice, sonophoresis is commonly used in rehabilitation medicine and dermatology because of its role in increasing the permeability of drugs (such as arthritis, Paget disease, keloid and hypertrophic scars). ${ }^{27,28}$ With the development of ultrasonic technology, sonophoresis also has been used in anesthesia and gene therapy. ${ }^{29,30}$ A recent study reported the use of HFS for the delivery of a monoclonal antibody to different in vitro cancer cell lines for treatment against human papilloma virus (HPV) oncoprotein E6. ${ }^{31}$
However, there have been controversies regarding its efficacy on different drugs. Dakowicz et $\mathrm{al}^{32}$ investigated the efficiency of ultrasound therapy in combination with iontophoresis and hydrocortisone for the management of carpal tunnel syndrome (CTS) in 40 patients and found that the combined modalities improved symptoms in this cohort of patients. Silveira et $\mathrm{al}^{33}$ investigated the impact of dimethylsulfoxide (DMSO) phonophoresis and therapeutic pulsed ultrasound (TPU) on levels of oxidative stress in traumatized muscle and revealed that DMSO was able to effectively reduce muscular oxidative only when applied in conjunction with TPU. On the other hand, Kuntz et $\mathrm{al}^{34}$ found that $10 \%$ hydrocortisone phonophoresis treatment failed to raise human skeletal muscle tissue concentrations of cortisol. Studies on sonophoresis for the delivery of chemotherapy drugs have rarely been studied, given its potentially inflammatory effect on tissues. The inconsistency of ultrasound parameters (PTU) and concentration of administered drug might be the primary cause of incongruent results across the studies. Therefore, our study involved the use of a replicable cisplatin treatment method protocol (using the optimal PTU and the property drug concentration) in order to further investigate the use of sonophoresis-enhanced drug delivery.

Yingjie et $\mathrm{al}^{35}$ established the model of kidney injury induced by cisplatin in rats and found that the content of cisplatin in renal tissue is the highest on the fifth day. This timepoint was also when the most severe renal damage was observed. Huizhu et $\mathrm{al}^{36}$ revealed similar findings on hepatic ultrastructure damage using rat models of acute hepatic injury induced by cisplatin. Given the above evidence, our study investigates skin, liver and kidney injury at 5 days after the first administration of cisplatin to research the safety of cisplatin concentration for sonophoresis. Ye et $\mathrm{al}^{37}$ studied the impact of low-intensity ultrasound and HEp-2 cell apoptosis and found that ultrasound altered expressions of Bax, Bcl-2 and caspase-3 while markedly raising intracellular $\mathrm{Ca}^{2+}$ concentrations. Meanwhile, Shi et $\mathrm{al}^{38}$ found that low-intensity-pulsed ultrasound application in human hepatocellular carcinoma cells modulated the Cav-1/STAT3 signaling pathway. We concluded that the aforementioned pathway may be the upstream pathway of ultrasound-related apoptosis. This investigation studies the impact of sonophoresis combined with cisplatin through the detection of apoptotic protein markers MPO, Caspase-3 and TUNEL, and the proliferation factor PCNA. Our study indicates that ultrasound-enhanced transdermal delivery of cisplatin in the nude-mouse model of cervical cancer under the therapeutic pulsed ultrasound at an intensity of $2.0 \mathrm{~W} / \mathrm{cm}^{2}$ and frequency of $1.0 \mathrm{MHz}$ for a duration of 60 


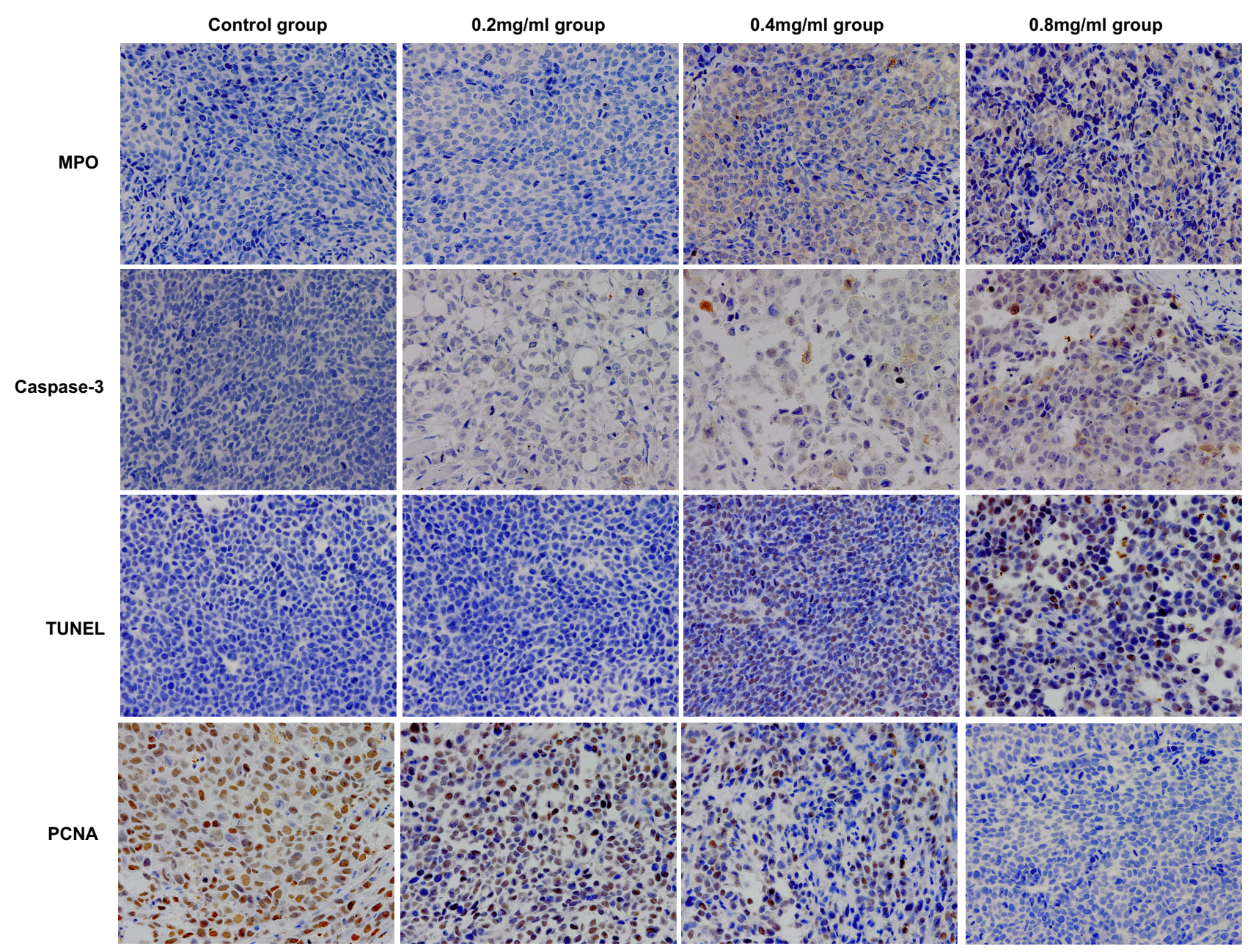

Figure 6 Representative immunohistochemical images of each factor in the different groups on day 5.

mins efficiently increased with the concentration of cisplatin. This finding is consistent with that of Rosim et $\mathrm{al}^{39}$ who researched diclofenac phonophoresis in human volunteers and found that pre-applied ultrasound irradiation augmented transdermal delivery of topical diclofenac gel, with higher drug concentrations yielding higher transdermal delivery. While higher drug concentrations $(0.8 \mathrm{mg} / \mathrm{mL})$ have the advantage of high drug permeability and therefore higher tumor apoptosis rate, it also imparts undesirable side effects such as skin inflammation response and renal injury, which in our study was directly responsible for decreased appetite and weight loss in the model animals. A major limitation of transdermal application of chemotherapeutic drugs is the effect of necrosis and inflammation on the local tissue of the application site.

In this study, we found that the medium concentration $(0.4 \mathrm{mg} / \mathrm{mL})$ was able to administer satisfactory levels of cisplatin transmittance rate and had acceptable rates of tumor apoptosis while imparting no obvious damage to the skin, kidney and liver. Cisplatin in low concentration
$(0.2 \mathrm{mg} / \mathrm{mL})$ group did not demonstrate obvious changes in HLPC, with no differences between cellular proliferation and apoptosis between this group and the control group. There was no tumor-inhibition effect was observed in each group during the intervention, possibly due to insufficient observation time (only 5 days). It was noticed that the weight of tumor was heavier in the middle and high concentration groups (even though there was no statistical difference $(P>0.05))$, we suggest that this observation was related to tumor necrosis and inflammatory cell infiltration that was observed on HE staining and TEM visualization.

Based on our observations, we considered that the concentration of $0.4 \mathrm{mg} / \mathrm{mL}$ might be the most appropriate concentration for sonophoresis-assisted drug delivery on a xenografted tumor model of cervical cancer. However, our study has a number of limitations. First, our research utilized ordinary cisplatin solution $(\mathrm{NaCl})$ only. Second, our study only investigated the impact of cisplatin on our animal models at a single timepoint (5 days). This timepoint may be 


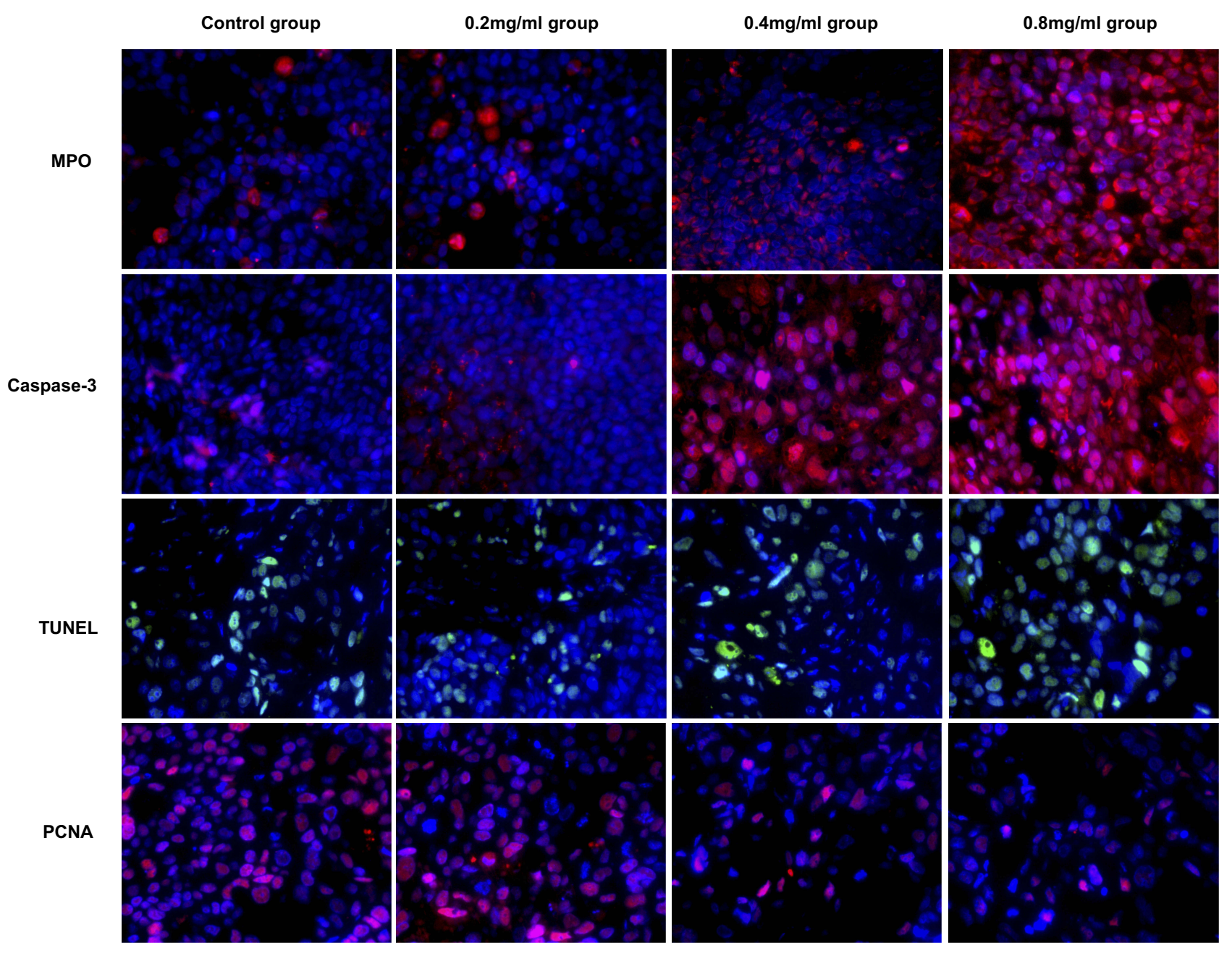

Figure 7 Representative immunofluorescence images of each factor in the different groups on day 5 .

insufficient to evaluate the tumor suppression effect and injury of other organs. Third, the upstream pathway of ultrasound-related apoptosis was not further explored. At the beginning of the research design, we considered that as an auxiliary drug of chemotherapy and radiotherapy, simple and direct drug dispensing might be more economical and convenient for patients to accept. Meanwhile, the long-term curative effect, other side effects and the underlying molecular mechanisms will require further exploration by our group. Furthermore, the use of chemical penetration enhancers (CPEs) to attain a higher amount of permeabilization and the combination with other therapies for cervical cancer also should be researched.

\section{Conclusions}

Sonophoresis enhanced transdermal delivery of cisplatin in xenograft tumor model of cervical cancer under the therapeutic pulsed ultrasound at an intensity of $2.0 \mathrm{~W} / \mathrm{cm}^{2}$ and frequency of $1.0 \mathrm{MHz}$ for a duration of 60 mins. The effect of this adjunct was concentration dependent. Considering the limitation of skin inflammation and renal injury caused by cisplatin, the recommended concentration is $0.4 \mathrm{mg} / \mathrm{mL}$. Although a significant inhibition in tumor growth was not observed because of the short observation time, sonophoresis did increase the concentration of cisplatin in tumor and induced apoptosis and inflammatory response. Meantime, no irreversible damage to the liver, kidney or skin tissue was observed. Sonophoresis drug transdermal delivery, as an adjuvant administration method combined with conventional chemotherapy, enhanced the local drug concentration without increasing nephrotoxicity or hepatotoxicity. It provides a novel idea for the comprehensive treatment of cervical cancer.

\section{Ethics Statement}

All animal experiments and care administered were approved by the Guangxi Medical University Animal Care and Use 
Committee, People's Republic of China. All experiments were conducted in accordance with the approved guidelines (the National Standard GB/T35892-2018 of the People's Republic of China). All efforts were made to minimize the suffering of mice (eg, the minimum concentration of drugs and pentobarbital sodium was applied) and the minimum number of mice was used to meet the valid statistical evaluation based on the guidelines of the animal ethics committee of the institute.

\section{Acknowledgments}

The authors would like to thank Dr. Shunyu Lu from Pharmaceutical College, Guangxi Medical University for the advice on pharmacology, Dr. Junjun Jiang from School of Public Health, Guangxi Medical University for assisting in statistical analysis.

\section{Funding}

This work was supported by the Research Project of Guangxi Health and Family Planning Commission (Z20180924, Z201 80925), Guangxi Science and Technology Program Project (GK AD17129017, GK AD17195042 and GK AD17 129013), Guangxi Science and Technology Cooperation and Exchange Project (GKH 159905-2-11) and Central Leading Local Science and Technology Development Special Fund Project (GK ZY18076006). The funders had no role in study design, data collection and analysis, decision to publish, or preparation of the manuscript.

\section{Disclosure}

The authors report no conflicts of interest in this work.

\section{References}

1. Forouzanfar MH, Afshin A, Alexander LT, GBD 2015 Risk Factors Collaborators. Global, regional, and national comparative risk assessment of 79 behavioural, environmental and occupational, and metabolic risks or clusters of risks, 1990-2015: a systematic analysis for the Global Burden of Disease Study 2015. Lancet. 2016;388 (10053):1659-1724. doi:10.1016/S0140-6736(16)31679-8

2. Ben-Yakov G, Alao H, Haydek JP, et al. Development of hepatic steatosis after chemotherapy for non-hodgkin lymphoma. Hepatol Commun. 2019;3(2):220-226. doi:10.1002/hep4.1304

3. Woopen H, Richter R, Chekerov R, et al. Prognostic role of chemotherapy-induced nausea and vomiting in recurrent ovarian cancer patients: results of an individual participant data meta-analysis in 1213. Support Care Cancer. 2019;28:73-78.

4. Naveed S, Thappa DM, Dubashi B, Pandjatcharam J, Munisamy M, Singh N. Mucocutaneous adverse reactions of cancer chemotherapy and chemoradiation. Indian $J$ Dermatol. 2019;64(2):122-128. doi:10.4103/ijd.IJD_129_17

5. Tianze Z, Guangwei X, Yi W, et al. Oncology [M]. Tianjin: Tianjin Science and Technology Press. 2005;535-930.
6. Ghosh S. Cisplatin: the first metal based anticancer drug. Bioorg Chem. 2019;88:102925. doi:10.1016/j.bioorg.2019.102925

7. Bray F, Ferlay J, Soerjomataram I, Siegel RL, Torre LA, Jemal A. Global cancer statistics 2018: GLOBOCAN estimates of incidence and mortality worldwide for 36 cancers in 185 countries. CA Cancer J Clin. 2018;68(6):394-424. doi:10.3322/caac.v68.6

8. Suh DH, Kim M, Kim K, Kim HJ, Lee KH, Kim JW. Major clinical research advances in gynecologic cancer in 2016: 10-year special edition. J Gynecol Oncol. 2017;28(3):e45. doi:10.3802/jgo.2017.28. e45

9. Thomas GM. Improved treatment for cervical cancer-concurrent chemotherapy and radiotherapy. $N$ Engl $J$ Med. 1999;340 (15):1198-1200. doi:10.1056/NEJM199904153401509

10. Rose PG, Bundy BN, Watkins EB, et al. Concurrent cisplatin-based radiotherapy and chemotherapy for locally advanced cervical cancer. N Engl J Med. 1999;340(15):1144-1153. doi:10.1056/NEJM1999041 53401502

11. Keys HM, Bundy BN, Stehman FB, et al. Cisplatin, radiation, and adjuvant hysterectomy compared with radiation and adjuvant hysterectomy for bulky stage IB cervical carcinoma. $N$ Engl J Med. 1999;340(15):1154-1161. doi:10.1056/NEJM199904153401503

12. Morris M, Eifel PJ, Lu J, et al. Pelvic radiation with concurrent chemotherapy compared with pelvic and para-aortic radiation for high-risk cervical cancer. $N$ Engl J Med. 1999;340(15):1137-1143. doi:10.1056/NEJM199904153401501

13. Whitney CW, Sause W, Bundy BN, et al. Randomized comparison of fluorouracil plus cisplatin versus hydroxyurea as an adjunct to radiation therapy in stage IIB-IVA carcinoma of the cervix with negative para-aortic lymph nodes: a Gynecologic Oncology Group and Southwest Oncology Group study. J Clin Oncol. 1999;17 (5):1339-1348. doi:10.1200/JCO.1999.17.5.1339

14. Higo N. Recent trend of transdermal drug delivery system development. Yakugaku Zasshi. 2007;127(4):655-662. doi:10.1248/ yakushi.127.655

15. Mitragotri S. Sonophoresis: a 50-year journey. Drug Discov Today. 2004;9(17):735-736. doi:10.1016/S1359-6446(04)03209-X

16. Prausnitz MR, Langer R. Transdermal drug delivery. Nat Biotechnol. 2008;26(11):1261-1268. doi:10.1038/nbt.1504

17. Oberli MA, Schoellhammer CM, Langer R, Blankschtein D. Ultrasound-enhanced transdermal delivery: recent advances and future challenges. Ther Deliv. 2014;5(7):843-857. doi:10.4155/tde. 14.32

18. Castelão C, da Silva AP, Matos A, et al. Association of myeloperoxidase polymorphism (G463A) with cervix cancer. Mol Cell Biochem. 2015;404(1-2):1-4. doi:10.1007/s11010-015-2359-5

19. Haider T, Tiwari R, Vyas SP, Soni V. Molecular determinants as therapeutic targets in cancer chemotherapy: an update. Pharmacol Ther. 2019;200:85-109. doi:10.1016/j.pharmthera.2019.04.011

20. Moldovan GL, Pfander B, Jentsch S. PCNA, the maestro of the replication fork. Cell. 2007;129(4):665-679. doi:10.1016/j. cell.2007.05.003

21. Park D, Yoon J, Park J, Jung B, Park H, Seo J. Transdermal drug delivery aided by an ultrasound contrast agent: an in vitro experimental study. Open Biomed Eng J. 2010;4:56-62. doi:10.2174/ 1874120701004010056

22. Li WF, Niu XF, Fan T, et al. High-performance liquid chromatography-based determination of plasma and renal tissue cisplatin levels after subcutaneous cisplatin implantation in mice. J South Med Univ. 2010;30(02):242-244.

23. Tian J, Pang X, Yu K, Liu L, Zhou J. Precolumn derivatization HPLC for pharmacokinetics of cisplatin nanoparticles in rats. $J$ Shenyang Pharm Univ. 2017;34(02):158-163.

24. Newman MK, Kill M, Frampton G. Effects of ultrasound alone and combined with hydrocortisone injections by needle or hypo-spray. Am J Phys Med. 1958;37(4):206-209. 
25. Mitragotri S, Blankschtein D, Langer R. Ultrasound-mediated transdermal protein delivery. Science. 1995;269(5225):850-853. doi:10. 1126/science.7638603

26. Ghosh S, Blankschtein D. The role of sodium dodecyl sulfate (SDS) micelles in inducing skin barrier perturbation in the presence of glycerol. J Cosmet Sci. 2007;58(2):109-133.

27. Molina GE, Khalifian S, Mull JL, et al. Topical combination of fluorouracil and calcipotriene as a palliative therapy for refractory extramammary Paget disease. JAMA Dermatol. 2019;155 (5):599-603. doi:10.1001/jamadermatol.2018.4793

28. Ogawa R. Keloid and hypertrophic scars are the result of chronic inflammation in the reticular dermis. Int J Mol Sci. 2017;18(3):606. doi:10.3390/ijms18030606

29. Becker BM, Helfrich S, Baker E, Lovgren K, Minugh PA, Machan JT. Ultrasound with topical anesthetic rapidly decreases pain of intravenous cannulation. Acad Emerg Med. 2005;12 (4):289-295. doi:10.1197/j.aem.2004.11.019

30. Yu H, Xu L. Cell experimental studies on sonoporation: state of the art and remaining problems. J Control Release. 2014;174:151-160. doi:10.1016/j.jconrel.2013.11.010

31. Togtema M, Pichardo S, Jackson R, Lambert PF, Curiel L, Zehbe I. Sonoporation delivery of monoclonal antibodies against human papillomavirus 16 E6 restores p53 expression in transformed cervical keratinocytes. PLoS One. 2012;7(11):e50730. doi:10.1371/journal. pone.0050730

32. Dakowicz A, Latosiewicz R. The value of iontophoresis combined with ultrasound in patients with the carpal tunnel syndrome. Rocz Akad Med Bialymst. 2005;50(Suppl 1):196-198.
33. Silveira PC, Victor EG, Schefer D, et al. Effects of therapeutic pulsed ultrasound and dimethylsulfoxide (DMSO) phonophoresis on parameters of oxidative stress in traumatized muscle. Ultrasound Med Biol. 2010;36(1):44-50. doi:10.1016/j. ultrasmedbio.2009.09.001

34. Kuntz AR, Griffiths CM, Rankin JM, Armstrong CW, McLoughlin TJ. Cortisol concentrations in human skeletal muscle tissue after phonophoresis with $10 \%$ hydrocortisone gel. J Athl Train. 2006;41(3):321-324.

35. Yingjie Guan LZ. Preventive effect of N-methyl-D-glucamine against cisplatin nephrotoxicity in rats. $J$ Health Toxicol. 2000;14(2):95-98.

36. Karalurt Y, Uçak T, Yaşar I. The effect of lutein pretreatment on cisplatin-induced hepatic ultrastructure damage in rats. Tianjin Med J. 2012;40(5):490-492.

37. Shi M, Liu B, Liu G, et al. Low intensity-pulsed ultrasound induced apoptosis of human hepatocellular carcinoma cells in vitro. Ultrasonics. 2016;64:43-53. doi:10.1016/j.ultras.2015.07.011

38. Ye Q, Meng C, Shen Y, et al. Caveolin-1 mediates low-intensity ultrasound-induced apoptosis via downregulation of signal transducer and activator of transcription 3 phosphorylation in laryngeal carcinoma cells. Ultrasound Med Biol. 2016;42(9):2253-2260. doi:10.10 16/j.ultrasmedbio.2016.04.017

39. Rosim GC, Barbieri CH, Lanças FM, Mazzer N. Diclofenac phonophoresis in human volunteers. Ultrasound Med Biol. 2005;31 (3):337-343. doi:10.1016/j.ultrasmedbio.2004.11.012

\section{Publish your work in this journal}

OncoTargets and Therapy is an international, peer-reviewed, open access journal focusing on the pathological basis of all cancers, potential targets for therapy and treatment protocols employed to improve the management of cancer patients. The journal also focuses on the impact of management programs and new therapeutic agents and protocols on patient perspectives such as quality of life, adherence and satisfaction. The manuscript management system is completely online and includes a very quick and fair peer-review system, which is all easy to use. Visit http://www.dovepress.com/ testimonials.php to read real quotes from published authors. 